\title{
Nest building and description of parental care behavior in a temperate reef fish, Chromis crusma (Pisces: Pomacentridae)
}

\author{
Teresa Navarrete-Fernández ${ }^{1}$, Mauricio F Landaeta ${ }^{2}$, Claudia A Bustos ${ }^{2,3}$ and Alejandro Pérez-Matus ${ }^{1 *}$
}

\begin{abstract}
Background: Subtle ecological and behavioral mechanisms that enhance reproduction such as nest building by animals may provide useful information of population level processes. Variation in behavioral traits may be observed as phenotypic traits that are shaped by sexual and natural selection. Using ecological sampling of benthic substrata and underwater video recordings, we assessed nest-building behavior through habitat modifications, and size of individuals performing parental care behavior and egg/hatching traits of an abundant temperate reef fish, Chromis crusma.

Results: We identified that only male individuals performed nest building and uniparental care. We noted that nests containing filamentous green or red algae had the highest percent cover of eggs. Using video recordings, we provided evidence of parental care. Male individuals spent nearly $80 \%$ of their time inside the nest, aerating the eggs with their fins and mouth, removing unwanted materials, and defending the nest against conspecific, heterospecific, and other predators. The field-collected eggs, characterized by an oil globule and adhesive filaments, hatched after 7 days in the laboratory. The nest-building and parental care behavior of C. crusma lasted for 3 months, and several nests can be constructed throughout the season.
\end{abstract}

Conclusion: The behavior of building and defending the nests, which is a characteristic of the family members, is a key aspect for the success of the C. crusma; this fish is abundant in kelp ecosystems of the southeastern Pacific.

Keywords: Reproductive strategies; Parental care; Reef fishes; Chile

\section{Background}

Plants and animals have evolved to ensure the survival of their own future genes, thus affecting the number of offspring for future generations (Gross 2005). Furthermore, natural selection is expected to favor behaviors that maximize lifetime reproductive success where mixtures of behavioral phenotypes may exist among species and populations (Alcock 2009). Individuals must therefore perform a series of behaviors to obtain their optimum reproduction over the course of a lifetime (Darwin 1859). Teleost fish display a wide range of parental care behavior, ranging from no care at all, uniparental care by a female or male, to biparental care (Gross and Sargent 1985; Blumer 1982; Webb et al. 1999). In order to succeed in their

\footnotetext{
* Correspondence: aperez@bio.puc.c

'Subtidal Ecology Laboratory \& Marine Conservation Center, Estación Costera de Investigaciones Marinas, Pontificia Universidad Católica de Chile, Casilla 114-D, Santiago, Chile

Full list of author information is available at the end of the article
}

offspring's survival, individuals need to evaluate the benefits of conducting care, resulting in variation or termination of parental care behavior within populations (Ochi 1985; Smith and Wooton 1995).

The numerous costs associated to finding a mate, competing with conspecifics, courtship, and parental care are often assessed by individuals, allowing behavioral adjustments to minimize these costs (Itzkowitz 1990; Clotfelter et al. 2006). Parental care activities occur after fertilization. In fish, a common care activity is fanning, in which the parent moves the pectoral, anal, and/or pelvic fins over the egg clutch, eliminating sediments from the surrounding environment (Goulet 1995). More sophisticated parenting methods involve the movement of the mouth or branchial cavity, which in turn oxygenates the eggs and removes suspended sediments, or the direct, selective removal of damaged or dead eggs with the mouth (Goulet 1998; Ochi 1985). Chasing competitors and predators away from the nest are also important forms of 
parental care (Amundsen 2003). Egg characteristics may also be associated with adult behavior. For example, egg size and development time can depend on predominance and duration of parental care (Sargent et al. 1987; Shine 1978).

The most noticeable behaviors of several fish species for attracting mates are resource and mate monopolization (Blumer 1982; DeMartini and Sikkel 2006; Baylis 1981). Territorial fishes, for instance, can acquire mates by establishing a temporary breeding territory or nesting site through the formation of structures used to house eggs (Sikkel 1995; Rushbrook et al. 2008; Goulet 1998; Kawase et al. 2013). Among fishes, nest construction can be divided into three categories: a) excavations - burrows in gravel, sand, or mud (Kawase et al. 2013); b) simple walls piling up sand, pebbles and shells, and artificial substrata (Colin 1973); and c) cement - secreting chemicals from the kidneys to glue together algae, detritus, or sand (Rushbrook et al. 2008).

In marine benthic substrata, nest builders clean their nesting areas by removing and/or farming preferred substratum species in an area where eggs have been deposited (Unger and Sargent 1988; Klumpp and Polunin 1989). Nests can be pivotal for courtship because they may attract the opposite sex and provide shelter for the developing eggs (DeMartini and Sikkel 2006). Nest quality is expected to differ among individuals who construct them (Clotfelter et al. 2006). In marine environments, individuals may face several limitations in building nests such as a) bottom topography (e.g., vertical walls versus horizontal surfaces), b) abundance of preferred nest material, c) presence of heterosexual or conspecific breeding pairs (i.e., operational sex ratio), and d) ability to chase predators and competitors away from the nest (Coleman and Wilson 1998; Taborsky 1994).

Fishes from the family Pomacentridae are oviparous (DeMartini and Sikkel 2006), and there are substantial differences in the mating systems within members of this family in both temperate and tropical systems (see Table 1). Nest building along with parental care behavior has been observed in 25 species, 7 of which are temperate (Table 1 ). The male is responsible for parental care and nest building in $80 \%$ of the cases and biparental care in the remaining $20 \%$. Biparental care is present for tropical species only. The majority of the species that build nest do not discriminate the species in the substrata to lay their eggs. However, algal species (usually turf algae) was the preferred site for spawning for six species, three of them are temperate (including Chromis crusma) and two subtropical species. Artificial structures, dead coral, and shells are the preferred sites for six tropical species. Most tropical species deposit their eggs under crevices or rock boulders (Table 1).

Castañeta, C. crusma, is a common and widely distributed damselfish inhabiting the Southeast Pacific Ocean from
Santa Rosa Island ( $5^{\circ} \mathrm{SL}$ ), Ecuador, to Valdivia (39 $\mathrm{SL}$ ), Chile (Pequeño et al. 2005). Along the central Chilean coast, individuals are usually found in rock outcrops within depths of between 5 and $35 \mathrm{~m}$ and reef areas dominated by large brown macroalgae where they recruit (i.e., Lessonia trabeculata). Adults can reach up to $25 \mathrm{~cm}$ in total length (TL) and are often seen in large schools (up to 100 individuals) (Pérez-Matus et al. 2007). The diet of C. crusma is comprised mainly of planktonic species (Angel and Ojeda 2001). As a first step to understand variability in parental care and nest-building behavior of an abundant temperate reef fish, we describe the information about the nest and the type of parental care and correlated this behavior with descriptions of the benthic eggs and recently hatched larvae.

\section{Methods}

\section{Study site}

Field observations on nesting behavior were performed during 2011 to 2012 and nest-building behavior was observed during November 2011 through March 2012, which coincides with the spawning season of C. crusma at Zapallar, Valparaíso ( $32^{\circ} 33^{\prime} \mathrm{SL}$ to $71^{\circ} 28^{\prime} \mathrm{WL}$ ) (Figure 1). We searched for and surveyed nests along the depth distribution of C. crusma, within depths of between 5 and $35 \mathrm{~m}$. Large boulders covered with turf and calcareous crustose algae dominated the shallow sections of the study site, where kelp was sparsely distributed from 5 to $15 \mathrm{~m}$. Encrusting sessile fauna such as sponges (Halichondria sp. and Clionopsis platei) and sea anemones (Parazoanthus sp. and Anemonia alicemartinae) as well as filamentous green and red algae dominated the substratum from 15 to $30 \mathrm{~m}$ (Figure 1a,b).

\section{Habitat modifications by $C$. crusma}

We searched for demersal nests of C. crusma, defining a nest as an area containing eggs attached to a substratum that was guarded by an individual (Figure 1a,b). At each nest, we described the color of the fish and estimated the size of the nest defender using a 4-cm dive weight positioned $5 \mathrm{~cm}$ from the nest. Mean nest size $(\mathrm{cm})$ was calculated by averaging the maximum horizontal and vertical lengths of the nest measured to the nearest $0.5 \mathrm{~cm}$ using a measuring tape. We categorized the substratum slope where the nest was located as either a) vertical walls, b) horizontal platforms, or c) intermediate slope platforms. Differences in nest size among the substratum slope were tested using a one-way ANOVA. To meet ANOVA assumptions of normality and homoscedasticity of variance, we used a Cochran $c$-test and Fligner-Killeen test, respectively (Crawley 2007). To confirm our prior field observations that nest defenders were males, we randomly collected six adult individuals from six different guarded nests and determined the sex of each individual. 
Table 1 Review of type of nest among tropical and temperate pomacentrid members

\begin{tabular}{|c|c|c|c|c|c|c|}
\hline Species & Distribution & Lt & Type of nest & Egg & Sex & Reference \\
\hline Abudefduf abdominalis & Tropical: Eastern Central Pacific & 30 & Substratum & 7 & Male & Ridley 1978 \\
\hline Abudefduf luridus & Temperate: Eastern Atlantic & 15 & $\begin{array}{l}\text { Vertical walls, algae, } \\
\text { and sponges }\end{array}$ & ND & Male & $\begin{array}{l}\text { Ridley 1978; Mapstone and } \\
\text { Wood 1975 }\end{array}$ \\
\hline Abudefduf saxatalis & Temperate: Atlantic Ocean & 23 & Reef wall, crevices & 5 & Male & Reese 1964 \\
\hline Abudefduf taurus & Tropical: Western Atlantic & 25 & Crevices & 7 & Male & $\begin{array}{l}\text { Fishelson 1998; Mapstone } \\
\text { and Wood } 1975\end{array}$ \\
\hline Abudefduf zonatus & Tropical: Indo-Pacific & 13 & $\begin{array}{l}\text { Sand, under rock, and } \\
\text { coral rubble }\end{array}$ & ND & Male & $\begin{array}{l}\text { Ridley 1978; Mapstone } \\
\text { and Wood } 1975\end{array}$ \\
\hline $\begin{array}{l}\text { Acanthochromis } \\
\text { polyacanthus }\end{array}$ & Tropical: Western Pacific & 14 & Dead coral under rocks & 30 & Biparental & Ridley 1978; Robertson 1973 \\
\hline $\begin{array}{l}\text { Amblyglyphidodon } \\
\text { leucogaster }\end{array}$ & Tropical: Indo-West Pacific & 13 & $\begin{array}{l}\text { Dead coral or artificial } \\
\text { structures }\end{array}$ & 8 & Male & Goulet 1995, 1998 \\
\hline Amphiprion bicinctus & Tropical: Western Indian Ocean & 14 & Substratum & 6 & Biparental & Gittleman 1981 \\
\hline Amphiprion melanopus & Tropical: Pacific Ocean & 12 & Substratum & 9 & Biparental & $\begin{array}{l}\text { Breder and Rosen 1966; } \\
\text { Gittleman } 1981\end{array}$ \\
\hline Amphiprion percula & Tropical: Western Pacific & 11 & Substratum & 6 & Biparental & Ridley 1978 \\
\hline Amphiprion xanthurus & Tropical: Indo-West Pacific & 15 & Substratum & ND & Biparental & Gittleman 1981 \\
\hline Chromis caeruleus & Temperate: Mediterranean Sea & 9.5 & Green and turf algae & 4 & Male & Sale 1971 \\
\hline Chromis chromis & $\begin{array}{l}\text { Tropical and temperate: Eastern } \\
\text { Atlantic and Mediterranean Sea }\end{array}$ & 25 & Under crevices & 3 & Male & $\begin{array}{l}\text { Ridley 1978; Mapstone } \\
\text { and Wood } 1975\end{array}$ \\
\hline Chromis cyanea & $\begin{array}{l}\text { Tropical: Western Atlantic and the } \\
\text { Caribbean Sea }\end{array}$ & 15 & Under crevices & 4 & Male & Albrecht 1969; Ridley 1978 \\
\hline Chromis dispilus & $\begin{array}{l}\text { Temperate: Southwest Pacific } \\
\text { (New Zealand) }\end{array}$ & 21 & Substratum & 6 & Male & Kingsford 1985 \\
\hline Chromis multilineata & $\begin{array}{l}\text { Tropical: Western Atlantic and } \\
\text { the Caribbean Sea }\end{array}$ & 20 & $\begin{array}{l}\text { Under crevices, in } \\
\text { Sargassum sp. }\end{array}$ & 3 & Male & $\begin{array}{l}\text { Albrecht 1969; Myrberg } \\
\text { et al. } 1967\end{array}$ \\
\hline Chromis notata & $\begin{array}{l}\text { Temperate: southern Japan, } \\
\text { Ryukyu Islands, Taiwan, } \\
\text { and China }\end{array}$ & 17 & Substratum & $7^{a}$ & Male & Ochi 1985 \\
\hline Chromis punctipinnis & Temperate: Eastern Pacific & 25 & $\begin{array}{l}\text { Clean rock ledges or small } \\
\text { caves }\end{array}$ & 8 & Male & $\begin{array}{l}\text { Limbaugh 1964; Turner and } \\
\text { Ebert } 1962\end{array}$ \\
\hline Dascyllus aruanus & $\begin{array}{l}\text { Tropical and temperate: Indo-West } \\
\text { Pacific and north to southern Japan, } \\
\text { south to Sydney, Australia }\end{array}$ & 10 & Substratum & 3 & Male & Mizushima et al. 2000 \\
\hline Stegastes leucorus & Tropical: Eastern Central Pacific & 20 & Substratum & 3 to 5 & Male & Ridley 1978 \\
\hline Stegastes leucostictus & Tropical: Western Atlantic & 10 & Shells under crevices & 3 to 5 & Male & Ridley 1978 \\
\hline Stegastes partitus & $\begin{array}{l}\text { Tropical: Western Atlantic and the } \\
\text { Caribbean }\end{array}$ & 10 & Monolayer of species & 3 to 5 & Male & Knapp and Warner 1991 \\
\hline Hypsypops rubicunda & $\begin{array}{l}\text { Temperate and tropical: Eastern } \\
\text { Central Pacific and northern } \\
\text { central Baja California }\end{array}$ & 30 & Red algae & 3 & Male & Clarke 1970 \\
\hline Pomacentrus amboinensis & Tropical: Western Pacific & 15 & Dead coral & 4 & Male & $\begin{array}{l}\text { Murphy et al. 2007; } \\
\text { Maddams and } \\
\text { McCormick } 2012\end{array}$ \\
\hline Pomacentrus negasakiensis & Tropical: Indo-West Pacific & 11 & Boulders, artificial substrata & 4 & Male & Moyer 1975 \\
\hline Premnas biaculeatus & Tropical: Indo-West Pacific & 17 & Substratum & 7 & Biparental & Fishelson 1998; Ridley 1978 \\
\hline
\end{tabular}

Geographic distribution, total length of individuals (Lt, $\mathrm{cm}$ ), egg development in days (Egg), and sex of the individuals who perform care to their young. ND refers to not determined parameter. ${ }^{a}$ Mean number of days from 30 April until 24 August 1982 (Ochi 1985).

To describe nest habitat and substrate composition around the nest, we selected nests $(n=40)$ that were guarded by solitary individuals, and three quadrats were each randomly placed inside the nests, at the edge of the nests (along a boundary of the egg clutch), and outside the nests (where eggs are absent). In each quadrat, we recorded the percent cover of sessile benthic species using a $0.01-\mathrm{m}^{2}$ quadrat with 15 intersection points (random point contact, 

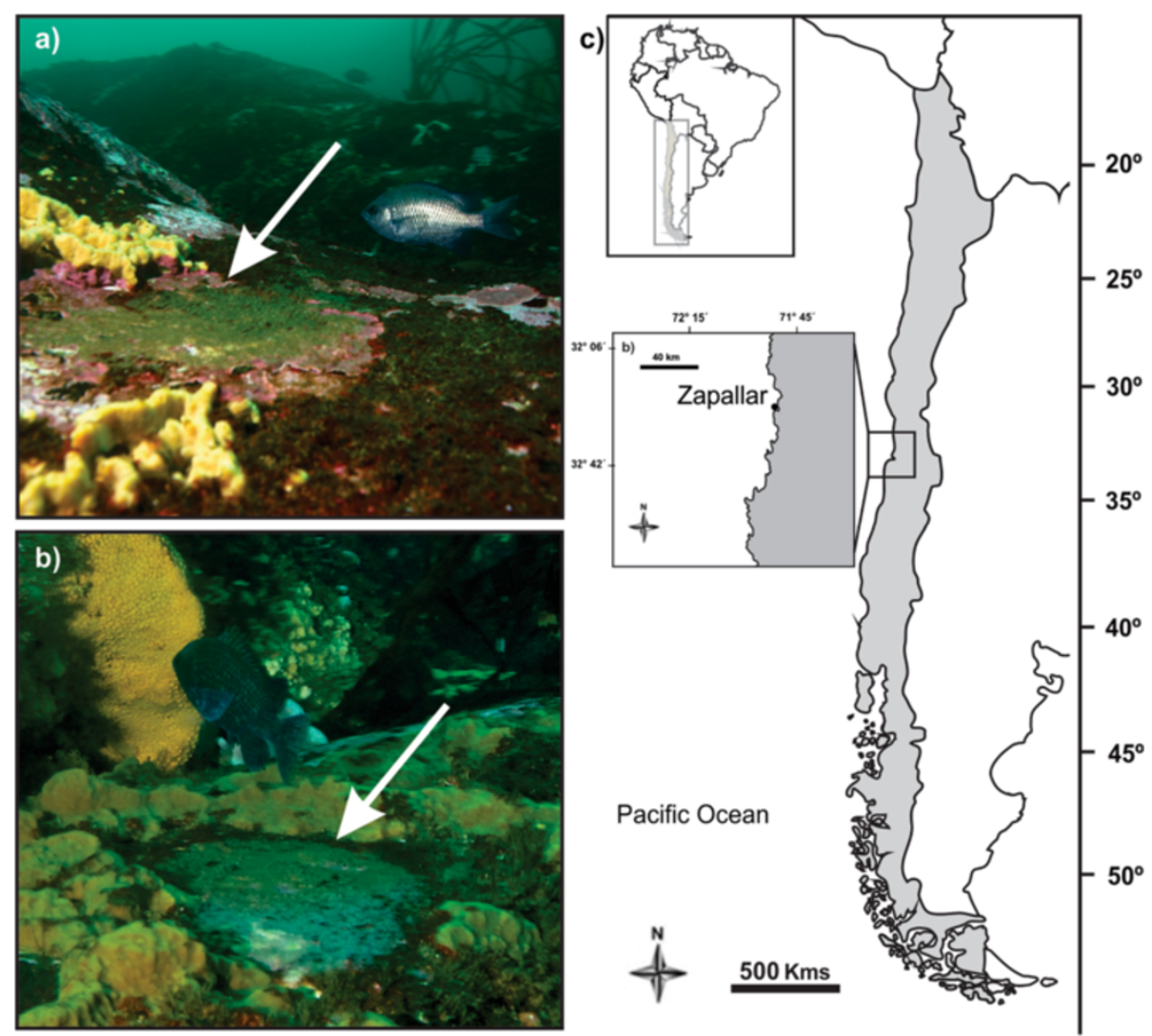

Figure 1 Photographs of the focal species and map showing the study sites. (a, b) Photographs of the focal species on its nest; arrows indicate nest position. (c) Map showing the study sites, lab-based studies.

RPC). We quantified the percent cover of eggs inside the nest. When necessary for confirmation of species identity, eggs and all sessile species were collected by manually removing with a spatula and preserved in 5\% buffered formalin. We also used underwater photography (NikonD90 with Ikelite Housing and two D125 substrobe; Ikelite Underwater Systems, Indianopolis, IN, USA) on quadrats to further analyze the images on a computer. The same divers performed all sampling by means of self contained underwater breathing apparatus (SCUBA) throughout the study.

To determine differences in the substrata composition inside and outside of nests, as well as among nests, we used multivariate analyses. A Bray-Curtis resemblance matrix was used to carry out the analysis, and a one-factor permutational multivariate analysis of variance (PERMANOVA; Anderson 2001) was used to test for significant differences in the substratum composition within and among the nests. At each spatial scale, the substratum species compositions were analyzed using similarity percentages (SIMPER), identifying the species that contributed most to the differences between the nest scales (i.e., outside, edge, inside). We estimated the nest quality by evaluating the relationship between species richness (i.e., benthic composition) and the number (i.e., percent cover) of eggs in each nest (Sikkel 1995).

\section{Parental care: nest-guarding behavior}

In order to avoid diver effects on the nest-guarding behavior (individuals tended to leave the nest when divers approached), we set up an underwater video camera (Go-Pro $^{\text {тм }}$ Hero 2, GoPro, Inc., San Mateo, CA, USA) anchored with a 2-kg weight. The total dimension of the camera was $8 \times 8 \mathrm{~cm}$. The camera was randomly positioned $30 \mathrm{~cm}$ from the nests, and the recording time ranged from 25 to $35 \mathrm{~min}$. We placed the camera in eight nests totaling approximately $280 \mathrm{~min}$ of recording time. Filming occurred during early egg development stages ( 2 to 3 days). Images were downloaded to a computer, and we quantified the time that each recorded individual spent performing the following: a) time inside the nest, b) aerating the eggs with the mouth, c) fanning with pectoral or anal fins, d) removing unwanted drift material, and e) defending the nest against intruders.

\section{Embryonic development and larval growth}

In order to describe the development time, hatching, and larvae growth of C. crusma, we collected eggs (>50) from more than ten nests at different depths using SCUBA and a scraping knife. The eggs were carefully placed in a 1-L glass container and transported in glass jars with seawater 
and ice packs to the laboratory $\left(32^{\circ} 56^{\prime} \mathrm{SL}, 71^{\circ} 33^{\prime} \mathrm{WL}\right)$ (Figure 1c). Once in the laboratory, egg clutches were kept aerated with filtered seawater $(0.5 \mu \mathrm{m})$ inside 5 - $\mathrm{L}$ glass jars at $18^{\circ} \mathrm{C}$. Embryo development was evaluated on a daily basis until hatching occurred (see below). Recently hatched larvae were transferred into 1 -L glass jars at a density of 30 larvae $\mathrm{L}^{-1}$. When the yolk sac was depleted, larvae were fed with Nannochloropsis spp. and rotifers Brachionus plicatilis.

During each monitoring, all eggs and larvae were photographed with a stereomicroscope Olympus SZ-61 equipped with a Motic video camera 2500 (5.0 MP; Olympus Corporation, Tokyo, Japan) connected to a PC with Moticam Image Plus 2.0 software. All measurements $(\mathrm{mm})$ were carried out on fresh eggs (length, maximum width, oil globule diameter) and larvae [body length (from the tip of the snout to the tip of the notochord), pre-anal length, eye diameter, yolk sac length and height, and oil globule diameter]. Egg and yolk sac volume were estimated considering the yolk sac as an ellipsoid $\left(V=4 / 3 \pi a b^{2}\right)$, where $a$ is half of the egg or yolk sac length ( $\mathrm{mm})$ and $b$ is half of the height (mm) (Bustos and Silva 2011). Larval growth was estimated adjusting a least squares linear regression model between body length $(\mathrm{BL}, \mathrm{mm})$ and age (days post hatch, dph), $\mathrm{BL}=\alpha+\operatorname{dph} \beta$, where $\alpha$ and $\beta$ are the size at hatching and larval growth rate respectively, estimated by the model. All statistical tests were performed using R v 2.14 (R Development Core Team 2012).

\section{Results}

Habitat modifications of C. crusma during the spawning season

According to our observations, reproductive behavior in C. crusma commenced in late October and ended in March (austral spring-summer). During this period, we sampled every 2 weeks, a total of six different sampling days. More than 80 nests were observed, and of these, a total of 39 nests were measured, with a mean diameter of $23.5 \mathrm{~cm}( \pm 5.2 \mathrm{SD})$. All adult individuals collected $(n=6)$ from the nests were males. All had dark grey coloring that differed from their pelagic counterparts and other benthic transients, who were pale grey in color. Our visual estimates revealed that nest defenders ranged from 15.0 to $21.5 \mathrm{~cm}$ TL, with a mean of $17.3 \mathrm{~cm}$ TL $( \pm 2.6 \mathrm{SD})$. There was no relationship between fish TL and nest diameter (linear regression $r^{2}=0.08, \mathrm{df}=1, F=0.09, p$ value $>0.05$ ). Mean nest size measured $21.3( \pm 2.2 \mathrm{SE}), 23.3( \pm 1.3 \mathrm{SE})$, and $24.6( \pm 1.5 \mathrm{SE}) \mathrm{cm}$ in vertical walls, intermediate slope, and horizontal platforms, respectively. No significant differences were observed in the size of the nest with respect to the substratum slope (one-way ANOVA, $\mathrm{df}=2$; $F=0.4, p$ value $>0.05$ )

In the study area, we recorded a total of 16 benthic species that covered the substratum outside, inside, and at the edge of the nests. Significant differences were found among these categories (one-way ANOVA, $\mathrm{df}=2$; $F=6.5, p$ value $<0.01)$. We detected more benthic species at the edge and outside of nests than inside them (Tukey post hoc, $p$ value $<0.01$, Figure 2). Moreover, outside and edge richness varied significantly among nests, mirroring local changes in the surrounding dominant community structure (i.e., sessile animal or algae-dominated substratum). In contrast, species richness inside of nests was low and similar among nests regardless of the surrounding community. In terms of nest quality, a significant negative relationship was observed between the percent cover of eggs and the number of benthic species (linear regression, $r^{2}=0.4, \mathrm{df}=1, F=7.1, p$ value $\left.<0.001\right)$. A high number of eggs were present in nests that contained a small number of species (Figure 3).

Defended nest habitats were composed predominantly of filamentous green algae (mostly Cladophoropsis herpestica) or red algae (mostly Pterosiphonia dendroidea or Schottera nicaeensis) and/or crustose algae (Lithothamnion sp.) (Figure 4). The benthic sessile community composition differed inside the nests compared with the species that covered the edge of the nest or outside of them (PERMANOVA, $\mathrm{df}=2$, pseudo $F=3.8, p$ value $<0.01)$. Cumulative contributions (SIMPER) of the most influential species indicated that green filamentous algae accounted for $54 \%$ and $56 \%$ of the differences between inside the nest and outside or edge of the nest, respectively. The percentage cover of these algae was higher inside the nests (Figure 4).

\section{Parental care: nest-guarding behavior}

The video recordings of C. crusma (see video, http:// vimeo.com/89531693) revealed that males spent between $80 \%$ and $95 \%$ of their total time inside rather than outside the nests. Fanning was the most frequent activity performed by C. crusma inside the nests, ranging from

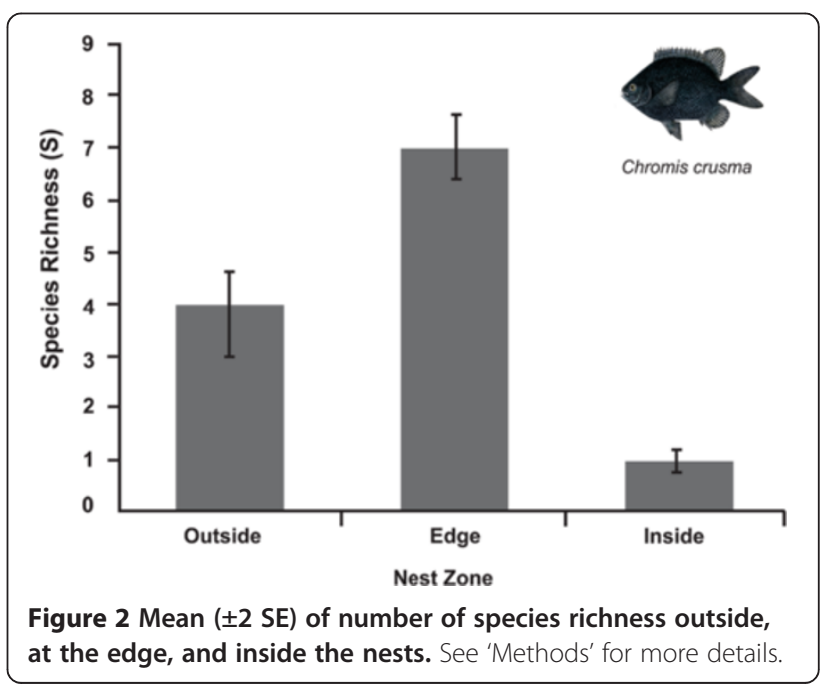




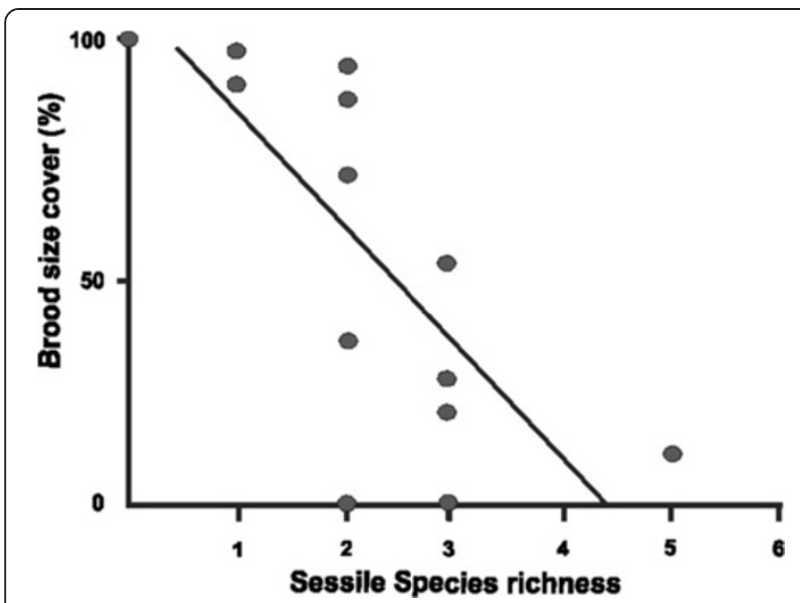

Figure 3 Relationship between numbers of benthic species with the percent (\%) cover of egg clutches. Linear tendency line is depicted.

$78 \%$ to $94 \%$ of the time. Defending the nest was the second most important activity ( $7 \%$ to $15 \%$ of the time). Predators such as the sandperch (Pinguipes chilensis), the triplefin (Helcogrammoides spp), and the rock shrimp (Rhinchocynetes typus) were excluded from the nest by exaggerated swims and accelerated chasing movements. The display of dorsal and pectoral fins was also an aggressive behavior performed by defending males. Only during short (few seconds), aggressive chases to ward-off potential predators and conspecifics would defending males leave the nest. In addition to protective behaviors, males were observed to actively aerate eggs by removing individuals and holding them within an open mouth faced directly in the direction of water flow for several seconds before placing them back in the nest. This was a commonly observed behavior (average of 24.5 events per individual) for the majority (95\%) of video/recorded individuals. Finally, the removal of drift material such as dead eggs and other detritus that can affect the normal development of the eggs was also observed.

\section{Embryonic development and larval growth}

The demersal eggs of C. crusma were ovoid to elliptical and ranged in size from 0.96 to $1.20 \mathrm{~mm}$ (mean: $1.08 \mathrm{~mm} \pm$ [0.06 SD], $n=50)$ on the long axis and 0.65 to $0.72 \mathrm{~mm}$ (mean: $0.68 \pm 0.02 \mathrm{~mm} \mathrm{SD}$ ) in maximum width. Estimated volume ranged from 0.23 to $0.30 \mathrm{~mm}^{3}$ (mean: $0.2 \pm$ $0.02 \mathrm{~mm}^{3} \mathrm{SD}$ ). Eggs contained one single red to yellow oil globule, 0.18 to $0.31 \mathrm{~mm}$ in diameter $(0.25 \pm 0.02 \mathrm{~mm} \mathrm{SD})$. Adhesive filaments attached eggs from their basal poles to the nest (Figure 5). Embryonic development lasted 7 to 8 days, and hatched larvae measured between 2.85 and $3.67 \mathrm{~mm}$ in body length (mean $3.30 \mathrm{~mm} \pm 0.18 \mathrm{SD}$ ), with a yolk sac of $0.021 \pm 0.004 \mathrm{~mm}^{3}$ (range: 0.013 to $0.030 \mathrm{~mm}^{3}$ ) that was generally depleted after $2 \mathrm{dph}$. The oil globule was completely absorbed after $7 \mathrm{dph}$. Both estimated slope (growth rate) and intercept (hatch size) were significantly different from zero ( $p$ value $_{\beta}=0.0014 ; p$ value $_{\alpha}<0.001$ ).

\section{Discussion}

Our results revealed that male individuals of C. crusma set up nesting territories during the austral summer (November through March), which they aggressively defend and actively clean/maintain. Moreover, males frequently undertook numerous 'incubating' activities that commonly benefit egg development, including aeration via fin fanning and exposing eggs to direct water flow, as well as egg re-positioning within the nest. The negative correlation between egg abundance and benthic species richness conforming nest substrate suggests that important differences in nest quality occur within a site, which

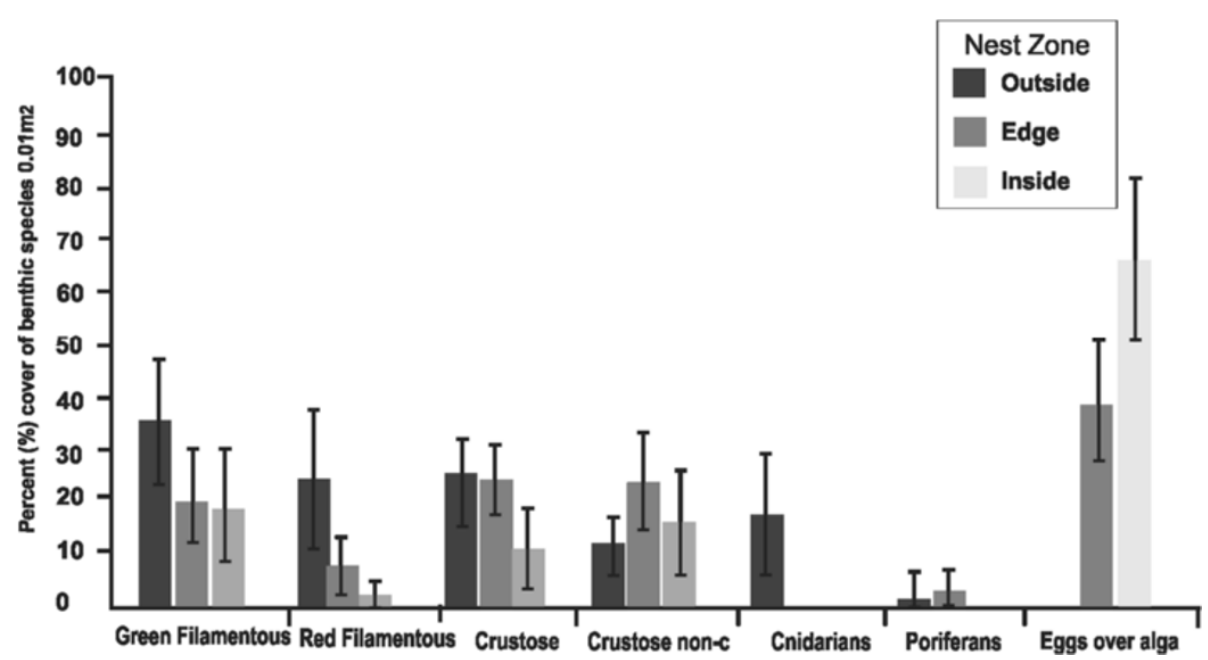

Figure 4 Mean ( \pm 2 SE) percent cover of sessile benthic species at the outside, edge, and inside the nests. 


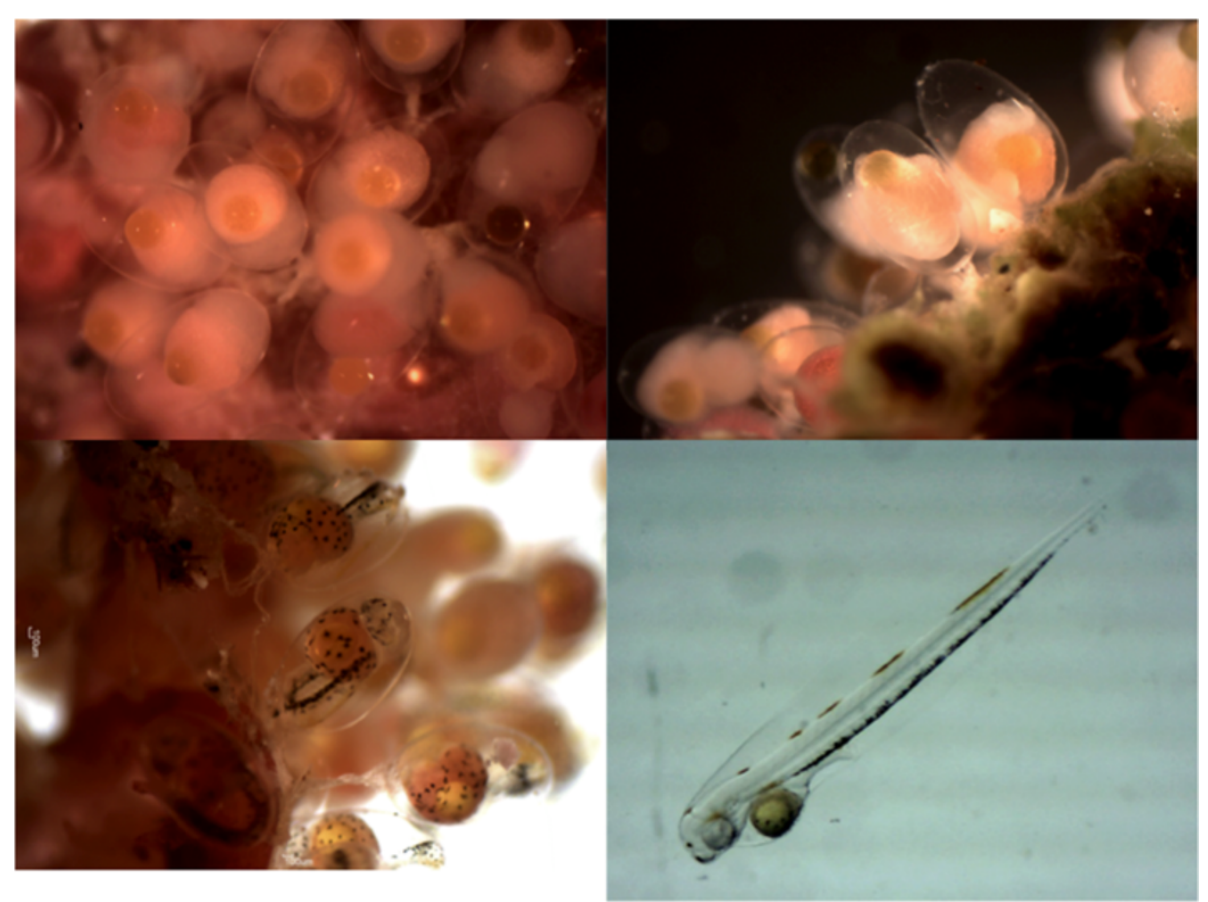

Figure 5 Photographs of different early developmental stages of castañeta Chromis crusma. Upper left panel, early gastrula; upper right panel, 12-somite stage; lower left panel, pre-hatching stage; lower right panel, recently hatched larvae. Stages according to Kingsford (1985).

was unrelated with the size (i.e., total length) of the individuals performing the care.

Male individuals responsible for the fate of the fertilized eggs and success during development result in uniparental care (Gross 2005). Males defend the nest against predators, aerate and fan the eggs, and remove drift materials from the nest during eight consecutive days after which larvae hatch in the laboratory at $18^{\circ} \mathrm{C}$. Finally, one oil globule and adhesive filaments characterize C. crusma eggs and many other members of the genera (see Kingsford 1985), which may explain the upkeep of benthic filamentous algae inside the nest by male individuals (as it allows egg attachment to the surface).

Methods of nest construction by C. crusma coincide with other temperate reef fishes of the family Pomacentridae (see Table 1). For example, the temperate damselfish Hypsypops rubicundus exhibits a similar behavior in the preparation of the nesting site, maintaining a red alga in the middle of the cleaned area, which is approximately 33 to $50 \mathrm{~cm}$ in diameter (Sikkel 1995). In general, temperate reef fish use benthic algae for depositing the eggs while tropical members use dead coral or artificial materials. Tropical members deposit eggs under crevices and boulders presumably to avoid egg predators, which are potentially more abundant in tropical reefs than predators in temperate reefs (Table 1 ).

Nest construction, in turn, can be crucial to increasing the reproductive success of male individuals. There is striking recent evidence, which suggests that nest and nest-building behavior have evolved under sexual selection (Borgia 1985; Tomás et al. 2013; Kawase et al. 2013). Nevertheless, a problem that has been puzzling behavioral ecologists is the identification of those aspects of the nest that influence the success of the spawning male, and thus determine what affects females in their selection of the spawning site (but see Tomás et al. 2013). In $C$. crusma, the identification of nest features that influence female choice can be complicated as is the case with many other fishes which perform parental care; females in many populations preferably spawn in nests that already contain eggs (Hoelzer 1990). Sex dissimilarities in shape, color, and behavior result from differences in the reproductive achievement of individuals (Clotfelter et al. 2006). Future research should be directed towards understanding the role of nest features as sexual signals (see Kawase et al. 2013).

A correlation between benthic sessile species and cover of eggs (as proxy of brood size) was observed in this study. It has been reported that size of the brood is crucial to the survival of offspring (see Ochi 1985). Sexual selection forces may well fit into this, as male individuals may have acquired information from past investments in nest building by carefully selecting sites where monospecific filamentous algae thrive. Alternatively, males can clean the substratum in such sites maintaining the preferred algae for females to deposit their eggs. The type of benthic 
substrata (not the bed-rock slope) may also be important for female choice in this species.

Considerable debate exists in the literature surrounding which hypothesis came first, the evolution of egg size (small vs large eggs) or the evolution of parental care. Shine (1978) proposed the 'safe harbor' hypothesis that predicts the evolution of parental care prior to the evolution of large egg size (selection favors the increase in egg size). Nussbaum and Schultz (1989) challenged this by stating that a form of care should be incorporated to reduce the long-term developmental mortality in relation to egg clutch size. Our study is not attempting to resolve this conflict. The high number of egg predators may indicate the high energetic lipid value and volume of C. crusma eggs (an oil globule), which correlates with the amount of energy spent by adults in maintaining predator distance. Differences in egg developmental time exist among tropical and temperate pomacentrids (Table 1). Egg development is similar among temperate reef fish, with time from egg deposit to hatching lasting 6 to 8 days for most temperate species and among tropical pomacentrids with 3 to 5 days for most tropical and subtropical pomacentrids. Some notable exceptions were present in tropical species such as Acanthochromis leucogaster, which exhibited extended egg development time of up to 30 days (Table 1). The longer time for egg development in temperate reef fish may directly affect the cost of parental care of individuals.

The complex life cycle (pelagic larval phase, benthic juvenile and adult) of most marine fishes is characterized by the high mortality of eggs and larvae. A bottleneck of population structure is often observed at the egg and larval stage. Therefore, nest construction and parental care may have important evolutionary consequences that affect local population structures (see Reynolds et al. 2002 for review). Temperate reef fish exhibit a diverse array of reproductive modes, life histories, and parental care systems. With substantial variation among individuals, the reproductive behavior of pomacentrid fishes can be divided into the establishment of a breeding territory, nesting site, construction of nests by building structures used to house eggs, courtship and pair formation, spawning and fertilization, and finally parental care (Limbaugh 1964; Clarke 1970; Sikkel 1995; Turner and Ebert 1962). To our knowledge, this is the first study which describes parental care carried out by a pomacentrid temperate reef fish in the southeastern Pacific. C. crusma is abundant within the reef system (Pérez-Matus et al. 2007). Modes of parental care have co-evolved in many taxa, and comparative information about young survivorship from different modes of reproduction is needed. Environmental and demographic parameters influencing parental care patterns are promising lines for future research.

\section{Conclusions}

Our results suggest that males Chromis crusma created their nest by removing some species from the substrate, selecting only sessile algae species for egg deposition. The number of sessile species removed may provide insights to the nest quality, which is unrelated to male's size. As in many other damselfish, egg development is longer in temperate that in tropical species. In laboratory, egg development lasted 7-8 days, which coincides with the time spent by individuals in defending their nest. Males aggressively defended their nest against predators, maintaining eggs by constantly aerating and cleaning eggs by removing drift material and repositioning eggs within the nest. Although this research provides a first step into the understanding of the biology and reproductive behavior of an abundant reef fish of the southeastern Pacific, environmental and demographic (i.e., operational sex ratio) parameters affecting this behavior requires further research.

\section{Competing interests}

The authors declare that they have no competing interests.

\section{Authors' contribution}

TNF and APM conceived the study, participated in the design and coordination of the manuscript, and carried out the field sampling. ML and CB carried out the larval description, development, analysis, and the written section. APM and TNF wrote the paper. All authors read and approved the final manuscript.

\section{Acknowledgements}

We would like to thank Ivo and Checho for providing boat assistance at the study site. This work was supported by Fondecyt under grant number 11110351 to APM. We would also like to thank Pilar Muñoz and Maibe Hermoso for their valuable help with macroalgae identification and laboratory analysis, respectively. This manuscript was improved by the comments and edits of Dr. Evie Wieters and two anonymous reviewers for their contribution in the manuscript. Dr. Sergio Carrasco and Samantha Goyen provided useful comments and edits to earlier versions of the manuscript.

\section{Author details}

${ }^{1}$ Subtidal Ecology Laboratory \& Marine Conservation Center, Estación Costera de Investigaciones Marinas, Pontificia Universidad Católica de Chile, Casilla 114-D, Santiago, Chile. ${ }^{2}$ Laboratorio de Ictioplancton (LABITI), Facultad de Ciencias del Mar y de Recursos Naturales, Universidad de Valparaíso, Avenida Borgoño 16344, Reñaca, Viña del Mar, Chile. ${ }^{3}$ Programa Doctorado en Acuicultura, Universidad Católica del Norte campus Guayacán, Larrondo 1281, Coquimbo, Chile.

Received: 1 August 2014 Accepted: 1 December 2014

Published online: 17 December 2014

\section{References}

Albrecht H (1969) Behaviour of four species of Atlantic damselfishes from Columbia, South America, (Abudefduf saxatiles, A. taurus, Chromis multilineata, C. cyanea; Pisces, Pomacentridae). Z Tierpsychol 26:662-676

Alcock J (2009) Animal behavior: an evolutionary approach. Sinauer Associates, Sunderland, USA

Amundsen T (2003) Fishes as models in studies of sexual selection and parental care. J Fish Biol 63 supplement A:17-52

Anderson MJ (2001) A new method for non-parametric multivariate analysis of variance. Austral Ecol 26:32-46

Angel A, Ojeda FP (2001) Structure and trophic organization of subtidal fish assemblages on the northern Chilean coast: the effect of habitat complexity. Mar Ecol Prog Ser 217:81-91

Baylis JR (1981) The evolution of parental care in fishes, with reference to Darwin's rule of male sexual selection. Environ Biol Fishes 6:223-251 
Blumer LS (1982) A bibliography and categorization of bony fishes exhibiting parental care. Zool J Linn Soc 75:1-2

Borgia G (1985) Bower quality, number of decorations and mating success of male satin bowerbirds Ptilonorhynchus violaceus: an experimental analysis. Anim Behav 33:266-271

Breder CMJ, Rosen DE (1966) Modes of reproduction in fishes. Natural history press, New York

Bustos CA, Silva A (2011) Endogenous feeding and morphological changes in hatchery-reared larval palm ruff Seriolella violacea Pisces: Centrolophidae under starvation. Aquacul Res 42:892-897

Clarke TA (1970) Territorial behavior and population dynamics of a pomacentrid fish, the garibaldi, Hypsypops rubicunda. Ecol Monogr 40:189-212

Clotfelter ED, Curren LJ, Murphy CE (2006) Mate choice and spawning success in the fighting fish Betta splendens: the importance of body size, display behavior and nest size. Z Tierpsychol 112:1170-1178. doi:10.1111/j.1439-0310.2006.01281.x

Coleman K, Wilson DS (1998) Shyness and boldness in pumpkinseed sunfish: individual differences are context-specific. Anim Behav 56:927-936

Colin PL (1973) Burrowing behavior of the yellowhead jawfish, Opistognathus aurifrons. Copeia 1:84-90

Crawley MJ (2007) The R book. John Wiley \& Sons, Ltd, Chichester, West Sussex, England

Darwin CR (1859) On the origin of species by means of natural selection, or the preservation of favoured races in the struggle for life. Murray, London

DeMartini EE, Sikkel PC (2006) Reproduction. In: Allen LG, Pondella DJ, Horn MH (eds) The ecology of marine fishes, vol 19. University of California Press, Berkele and Los Angeles, California, pp 483-523

Fishelson L (1998) Behaviour, socio-ecology and sexuality in damselfishes Pomacentridae. Ital J Zool 65 sup1:387-398, doi:10.1080/11250009809386853

Gittleman JL (1981) The phylogeny of parental care in fishes. Anim Behav 29:936-941

Goulet D (1995) Temporal patterns of reproduction in the Red Sea damselfish Amblyglyphidodon leucogaster. Bull Mar Sci 57:582-595

Goulet D (1998) Spawning success in the damselfish Amblyglyphidodon leucogaster: the influence of eggs in the nest. Anim Behav 55:651-664

Gross MR (2005) The evolution of parental care. Q Rev Biol 80:37-45. doi: 10.1086/431023

Gross MR, Sargent RC (1985) The evolution of male and female parental care in fishes. Am Zool 25(3):807-822

Hoelzer GA (1990) Male-male competition and female choice in the Cortez damselfish, Stegastes rectifraenum. Anim Behav 40:339-349

Itzkowitz M (1990) Sex ratio biasing and male reproductive variation in a coral-reef fish. Am Nat 136:557-559

Kawase H, Okata Y, Kimiaki I (2013) Role of huge geometric circular structures in the reproduction of a marine pufferfish. Sci Rep 3:1-6

Kingsford MJ (1985) The demersal eggs and planktonic larvae of Chromis dispilus Teleostei: Pomacentridae in north-eastern New Zealand coastal waters. N Z J Mar Freshwat Res 19:429-438

Klumpp DW, Polunin NVC (1989) Partitioning among grazers of food resources within damselfish territories on a coral reef. J Exp Mar Biol Ecol 125:145-169

Knapp RA, Warner RR (1991) Male parental care and female choice in the bicolo damselfish, Stegastes partitus: bigger is not always better. Anim Behav 41:747-756

Limbaugh C (1964) Notes on the life history of two Californian pomacentrids: garibaldis, Hypsypops rubicunda Girard, and blacksmith, Chromis punctipinnis Cooper. Pac Sci 18:41-50

Maddams JC, McCormick MI (2012) Not all offspring are created equal: variation in larval characteristics in a serially spawning damselfish. PLoS One 7:e48525. doi:10.1371/journal.pone.0048525.s013

Mapstone GM, Wood EM (1975) The ethology of Abudefduf luridus and Chromis chromis Pisces: Pomacentridae from the Azores. J Zool 175:179-199

Mizushima N, Nakashima Y, Kuwamura T (2000) Semilunar spawning cycle of the humbug damselfish Dascyllus aruanus. J Ethol 18:105-108

Moyer JT (1975) Reproductive behavior of the damselfish Pomacentrus nagasakiensis at Miyake-jima, Japan. Jap J Ichthyol 22:151-163

Murphy BF, Leis JM, Kavanagh KD (2007) Larval development of the Ambon damselfish Pomacentrus amboinensis, with a summary of pomacentrid development. J Fish Biol 71:569-584. doi:10.1111/j.1095-8649.2007.01524.x

Myrberg AA, Bradley JR, Brahy D, R. EA (1967) Reviewed field observations on reproduction of the damselfish, Chromis multilineata Pomacentridae, with additional notes on general behavior. Copeia 4:819-827
Nussbaum R, Schultz D (1989) Coevolution of parental care and egg size. Am Nat 133:591-603

Ochi H (1985) Termination of parental care due to small clutch size in the temperate damselfish, Chromis notata. Environ Biol Fishes 12:155-160

Pequeño G, Vargas L, Riedermann A (2005) La castañeta Chromis crusma Valenciennes, 1833 en la costa de Valdivia, con comentarios sobre el género Chromis Cuvier, 1814, en aguas chilenas Osteichthyes: Pomacentridae. Invest Mar 33:101-107

Pérez-Matus A, Ferry-Graham L, Cea A, Vásquez J (2007) Community structure of temperate reef fishes in kelp-dominated subtidal habitats of northern Chile. Mar Fresh Res 58(12):1069-1085

R Development Core Team (2012) R: A language and environment for statistical computing. The R Foundation for Statistical Computing, Vienna. http://www. R-project.org

Reese ES (1964) Ethology and marine zoology. Ann Rev Ocean Mar Biol 2:455-488

Reynolds JD, Goodwin NB, Freckleton RP (2002) Evolutionary transitions in parental care and live bearing in vertebrates. Phil Trans Royal Soc 357:269-281

Ridley M (1978) Paternal care. Anim Behav 26:904-932

Robertson DR (1973) Field observations on the reproductive behaviour of a pomacentrid fish, Acanthochromis polyacanthus. Z Tierpsychol 32(3):319-324

Rushbrook BJ, Dingemanse NJ, Barber I (2008) Repeatability in nest construction by male three-spine sticklebacks. Anim Behav 75:547-553

Sale PF (1971) The reproductive behaviour of the pomacentrid fish, Chromis caeruleus. Z Tierpsychol 29:156-164

Sargent RC, Taylor PD, Gross MR (1987) Parental care and the evolution of egg size in fishes. Am Nat 129:32-46

Shine R (1978) Propagule size and parental care: the 'safe harbor' hypothesis. J Theor Biol 75:417-424

Sikkel PC (1995) Effects of nest quality on male courtship and female spawning-site choice in an algal-nesting damselfish. Bull Mar Sci 57:682-689

Smith C, Wooton RJ (1995) The cost of parental care in teleost fishes. Rev Fish Biol Fish 5:7-22

Taborsky M (1994) Sneakers, satellites, and helpers: parasitic and cooperative behavior in fish reproduction. Adv Study Behav 23:1-100

Tomás G, Merino S, Martínez-de la Puente J, Moreno J, Morales J, Rivero-de-Aguilar 」 (2013) Nest size and aromatic plants in the nest as sexually selected female traits in blue tits. Behav Ecol 24:926-934

Turner CH, Ebert EE (1962) The nesting of Chromis punctipinnis Cooper and a description of their eggs and larvae. Calif Fish Game 48:243-248

Unger LM, Sargent RC (1988) Allopaternal care in the fathead minnow, Pimephales promelas: females prefer males with eggs. Behav Ecol Sociobiol 23:27-32

Webb JN, Houston Al, McNamara JM, SzéKely T (1999) Multiple patterns of parental care. Anim Behav 58:983-993. doi:10.1006/anbe.1999.1215

\section{doi:10.1186/s40693-014-0030-2}

Cite this article as: Navarrete-Fernández et al:: Nest building and description of parental care behavior in a temperate reef fish, Chromis crusma (Pisces: Pomacentridae). Revista Chilena de Historia Natural 2014 87:30

\section{Submit your manuscript to a SpringerOpen ${ }^{\circ}$ journal and benefit from:}

- Convenient online submission

- Rigorous peer review

- Immediate publication on acceptance

- Open access: articles freely available online

- High visibility within the field

- Retaining the copyright to your article

Submit your next manuscript at $\gg$ springeropen.com 